\title{
CONTENT AND LANGUAGE INTEGRATED LEARNING IN TERTIARY EDUCATION: PERSPECTIVES ON TERMS OF USE AND INTEGRATION
}

\author{
Olena Zarichna \\ ORCID: 0000-0002-6999-0538 \\ olenazarichna1977@gmail.com \\ Vinnytsia Mykhailo Kotsiubynsky State Pedagogical University, Ukraine \\ Svitlana Buchatska \\ ORCID: 0000-0001-6063-5858 \\ svitusik@gmail.com \\ Vinnytsia Mykhailo Kotsiubynsky State Pedagogical University, Ukraine \\ Liudmyla Melnyk \\ ORCID: 0000-0002-4025-0106 \\ rozdoba_l@ukr.net \\ Vinnytsia Mykhailo Kotsiubynsky State Pedagogical University, Ukraine \\ Tetiana Savchuk \\ ORCID: 0000-0003-1644-5357 \\ tetsav777@gmail.com \\ Vinnytsia Mykhailo Kotsiubynsky State Pedagogical University, Ukraine
}

Received March 22, 2020; Revised April 7, 2020; Accepted May 8, 2020

\begin{abstract}
This paper reports on a classroom investigation into a tertiary variation of content and language integrated learning (CLIL) as well as addresses the conceptual and methodological parameters of this method as distinguished from the other two content-based English-taught courses: ESP and EMI. A special challenge for this research was to study the functionality of CLIL in the university settings in terms of content retention and language acquisition as well as the development of communicative culture in university students. With this purpose we conducted a pilot project on CLIL also designing a triple vector observation scheme (content retention; language acquisition; communication culture) and adding the high order thinking skills dimension as a pivotal learning goal in a CLIL-based English classroom. The project comprised 8 syllabibased sub-modules that featured scientific content and was conducted among 78 humanities majors at Vinnytsia Mykhailo Kotsiubynsky State Pedagogical University, Ukraine. Findings show that students' cognitive and communicative needs do not find sufficient support in the existing L2 courses to which CLIL may serve as a solution. Introduction of CLIL even at the level of a variable sub-module may considerably raise students' satisfaction with L2 courses and provide a reliable backing in the development of their academic thinking and communicative culture.
\end{abstract}

Keywords: Content and Language Integrated Learning (CLIL), English for Specific Purposes (ESP), English as a Medium of Instruction (EMI), content-based instruction, Basic Interpersonal Communication System (BICS), Cognitive Academic Language Proficiency (CALP), high order thinking skills.

(C) Zarichna, Olena, Buchatska, Svitlana; Melnyk, Liudmyla; Savchuk, Tetiana, 2020. This is an Open Access article distributed under the terms and conditions of the Creative Commons Attribution 4.0 International Licence (http://creativecommons.org/licenses/by/4.0).

East European Journal of Psycholinguistics, 7(1), 184-198. https://doi.org/10.29038/eejpl.2020.7.1.zar 


\section{Зарічна Олена, Бучацька Світлана, Мельник Людмила, Савчук Тетяна.} Предметно-мовне інтегроване навчання у контексті вищої школи.

Анотація. У статті викладено результати дослідження предметно-мовного інтегрованого навчання (CLIL) в університетському контексті, розглянуто концептуальні та методологічні параметри цього методу у порівнянні 3 іншими двома англомовними дисциплінами, що зорієнтовані на навчання предметного змісту англійською мовою - ESP (Англійська мова професійного спрямування), ЕМI (викладання фахових дисциплін англійською мовою). Особливим завданням цього дослідження було вивчити функціональність методики CLIL в університетському середовищі щодо запам'ятовування контенту, засвоєння мови та розвитку комунікативної культури студентів. Із цією метою нами було здійснено пілотний CLIL-проєкт, для якого було створено тривекторний план спостереження 3 додаванням аспекту застосування операцій мислення вищого порядку, що є надважливою навчальною метою в контексті вивчення іноземної мови із застосуванням методики CLIL. До проєкту було залучено 78 студентів гуманітарних спеціальностей Вінницького державного педагогічного університету імені Михайла Коцюбинського, навчання здійснювалося на основі 8 тематичних субмодулів програмного змісту, які включали науковий контент. Результати дослідження показали, що когнітивні та комунікативні потреби студентів не дістають належного відгуку в поточних курсах іноземної мови, що може бути виправлено за допомогою CLIL. Упровадження CLIL бодай на рівні варіативних субмодулів може значно посприяти тому, аби студенти отримали очікувану користь від курсів іноземної мови й надати надійну підтримку в розвиткові культури їхнього наукового мислення і спілкування.

Ключові слова: предметно-мовне інтегроване навчання (CLIL), англійська мова професійного спрямування (ЕSP), викладання фахових дисциплін англійською мовою (ЕМI), предметно-орієнтоване навчання, базові навички міжособистісного спілкування (ВICS), когнітивна навчально-мовна компетентність (CALP), мислення вищого порядку.

\section{Introduction}

As a specific representation of the interdisciplinary approach in pedagogy, CLIL (Content and Language Integrated Learning) has received a wide range of interpretations on both theoretical and practical level. Incorporated in the form of a bilingual education scheme or a binary class system (subject teachers and language teacher working together in one classroom sharing study time and introducing material together in two different languages), it preserves its essence as an educational attempt to cater for the learner's need to simultaneously handle foreign language skill building, general knowledge acquisition, development of critical, creative and academic thinking as well as communicative competences.

The relevance of this issue is determined by the fact that the existing university EFL syllabi, being oriented at the "average" learner, does not pose sufficient and satisfying cognitive and linguistic challenge to high achieving representatives of the student population. This is the situation to which CLIL may serve as a solution.

Apart from the 4Cs (Content, Cognition, Communication, Culture) the theory of CLIL as a comprehensive approach also attaches functional concepts which we found relevant for this study. The theory of BICS (Basic Individual Communicative Skills) and CALP (Cognitive Academic Language Proficiency) by J. Cummins (Cummins, 1984) simultaneously reflects the core idea of CLIL and the algorithm of content learning: moving from cognitively undemanding context imbedded communication occurring at the initial stage of language learning to cognitively 
demanding context reduced communication involving added cognitive effort at the advanced stages of language acquisition. The learner, according to O. Meyer (Meyer, 2010), gradually passes the transition from BICS to CALP and thus mastering content, language, communicative and academic skills and knowledge.

\subsection{Statement of Purpose}

Despite very explicit definitions of CLIL as well as provenly successful practices (Fortanet-Gómez \& Bellés-Fortuño, 2008; Yang, 2016; Jiang, Jun Zhang, \& May, 2019), interpretations of its essence in Ukrainian and foreign academic writings reveal certain conceptual discrepancies: it is either being rebranded into a variation of ESP or its aspect or is just seen from the point of view of the guiding methodology, i.e. of creative teamwork, project work or problem-based learning combined (Grigorieva \& Salekhova, 2014; Znanetska, 2012). Another point of confusion, which we intend to bring into focus in this article, is lack of clear differentiation between the school and university formats of CLIL, ESP and EMI, which is critical for understanding the place of the three approaches in Ukrainian tertiary education. So, the research interests we attempted to cover in this article are represented in the following questions:

1. What is the place and role of CLIL as an innovative method in the tertiary education in Ukraine as compared and contrasted with the classical ESP and EMI courses, as well as school CLIL?

2. What are the challenges that CLIL implementers are to face?

3. How does the conception of CLIL correlate with students' needs and learning goals?

\subsection{Literature Review and Discussion}

Contriving to draw a division line between ESP and CLIL, scholars have come to varied conclusions: Fortanet-Gómez \& Bellés-Fortuño (2008) argue that ESP has the single aim of teaching and learning a foreign language, while CLIL places importance on content matter as well as the status of the language. Lasagabaster \& Sierra (2010) refer to CLIL as umbrella term, signifying an innovative educational approach by which a subject is taught in an additional language. The same idea is expressed by K. Grigorieva and L. Salekhova (Grigorieva \& Salekhova, 2014). K. Graham (2018) practically equates CLIL and EMI viewing both as a variation of CBI (content-based instruction).

While addressing the first question on the place and role of CLIL in Ukrainian tertiary education we attempted to draw a division line between three types of content-based EFL courses, i.e. ESP, EMI and actually CLIL referring to the content type, language acquisition model plus specific vocabulary and dominating methodology.

The first conclusion we have made was that school CLIL and university CLIL should be clearly differentiated. On the stage of secondary education the scope of subject matter the curricula encompass are exceedingly varied ranging from exact sciences to the humanities and arts. Learning a subject or a topic by means of a 
foreign language is claimed as hard or soft CLIL and there are no other subjectlanguage blends in the school curricula. At the university level, though, the situation is different: there are two other types of content-language blends which are not supposed to be confused with CLIL: a) ESP courses the aim of which is to train students to communicate in their professional field and make a rich input of the respective terminology; b) EMI courses in which English is used to teach academic subjects in countries or jurisdictions in which the majority of the population's first language is not English (Dearden, 2015). To paraphrase, EMI courses are typically professional degree courses taught in English. If we regard these two course types from the point of view of content-language ratio, we will clearly observe a selfsufficient construct in which ESP caters for the language acquisition and EMI for content learning. In this seemingly exhaustive scheme of content-based courses at the university level is CLIL to be perceived but as an unnecessary redundancy? The answer to this question naturally comes from an even superficial course content analysis. As an example, an EMI course of Political Science largely and primarily pertains to professional themes modified and changed with different frequency and intensity as well as expert knowledge acquisition. ESP courses involve miscellaneous text material for teaching grammar and terminology, but with a less heavy focus on in-depth profession-specific training and actually without the objective to ensure it as the main consideration is language. However, students of Psychology doing an ESP course learn the same type of content as those doing EMI: the knowledge essential for their degree qualifications, i.e. knowledge not provided to students majoring in Geography or Primary Education.

The literature review and a systematic analysis of the existing approaches and practices in the CLIL domain have led us to a set of assumptions that further determined our course of research in conducting a pilot CLIL project at university level.

1. Unlike school CLIL which means mastering a subject through a foreign language as a medium, university curricular have two other content-language courses: EMI and ESP, whose difference from CLIL is still to be determined and. The specificity of university CLIL is not only in the double content-language focus but also in the fact that it should be introduced only as interdisciplinary subject matter. If the content suggested relates directly to the students' degree specialization, it automatically becomes ESP or EMI. This may either be a comprehensive course not referring to any concrete specialty (e.g. "Media Literacy", "Academic Mobility" etc.) or a thematic complementation to the EGP or ESP courses providing extra-syllabus content relevant for any modern information consumer as well as information creator, regardless of which degree course they are doing. Importantly, CLIL content is to be viewed as non-major and crosscurriculum content.

2. As CLIL is not to refer to students' professional field it is only possible in the format of soft CLIL. To this format we may refer the recently created psychological, biological, economic and historic content, principally new and engaging, which supplements the background knowledge of a specific topic as well as of a specific subject. Generally, the content base of the existing EGP university courses is subdivided into topics, the major aim of which is to enrich the students' 
vocabulary for them to be able to name things and phenomena that they already tacitly know. That is to re-teach them the subject matter that they previously learnt. CLIL offers the type of knowledge that is completely or partially new, explicated and introduced into students' picture of the world. In this regard namely CLIL may constitute the developmental aspect of language education at tertiary level.

3. The major challenges CLIL implementers currently face are related to the course structure and also chronology of language learning occurrences. ESP courses are taught primarily in the first two years of a degree course while the disciplines referring to students' professional domain and thus the specific content with its terminology that can be used for ESP practices appears later, in the third year, for example. This means that if CLIL should be implemented in Ukrainian tertiary education, the scheduling of the curricula should be done in correlation between degree and ESP courses. To further on, the frequently mentioned dilemma of who should teach CLIL - a subject or a language teacher has an outcome in the English teacher having to master professional trivia of the field their students major in. CLIL endeavors are not submitted to a local board of experts for approval, thus the schools and universities that propose them are essentially self-referential or rely heavily on the set book CLIL content. On account of this situation, any teacher, also in collaboration with students, can decide to set up CLIL in this or that variation. It has not been specified what kind of assessment system is to be applied concerning language vs. content point distribution.

A summary table of the conceptual features of CLIL, EMI and ESP in comparison and contrast is introduced in Appendix.

\section{Methods}

\subsection{Context of research and participants}

Finding institutional support in conducting this research at Vinnytsia Pedagogical University we launched a pilot CLIL project comprising 8 syllabibased sub-modules featuring scientific content. First-year humanities majors meeting the threshold English proficiency level ( $N=78$, divided into 7 groups) and 3 EGP teachers gave their consent to participation in this study. By the time this research was conducted the students had undertaken 1 semester of the EGP course. The homogeneous versus mixed-ability contingent was selected on the assumption that language inadequacy in the project participants may appear to be a serious impediment in meeting the research goals.

\subsection{Data collection and analysis}

To maximally cater for the objectives of the research, a mixed-method design was employed. Data was collected through 1) direct observation structured according to an observation plan; 2) a post-observation questionnaire survey designed to locate the students' learning motivation and impressions of the project; 3) a semi-structured post-observation interview and field notes content analysis.

\subsection{Pilot Project Design}

The CLIL was introduced as a variative component to each of the staple program units following the BICS $\rightarrow$ CALP principle and employing a wide range of 
active methods of learning. Avoiding banalty, redundancy and thus reappearance of the already studied or the obvious, we specifically aimed at the students' using the newly received knowledge, introducing it into practical solutions, negotiation, persuasion, reflection on the subject matter. The assignments were deliberately designed so that the learners make extensive use of the H.O.T.s, summarize and analyse their cognitive and emotional experiences, synthesize and re-dimension the subject-matter areas dealt with in the course of the project.

Table 1

Provisional syllabus unit contents

\section{Staple Topic University. Student Life.}

Content focus Culture Shock: Stages, Features, Solutions.

(Thread)

Language input Psychological terminology.

Adjectives describing emotional states.

Present Simple active and passive.

Grammar structures used for expressing advice and opinion: should, had better, why not..., a good idea is..., in my view, as far as .... is concerned etc.

H.O.T. output: Prognostic thinking; analysis; critical thinking; emotional intellect competences, comparison, categorization, classification.

Communicative Ethical communication, persuasion techniques. competences BICS stage

1) Entry discussion.

2) Creating infographic images of individual experience of culture shock with their further analysis (cause-effectsolution algorithm).

3) Creating a group summary poster.

CALP stage 1) Introduction of the subject matter with the preliminary focus on language and scaffolding.

2) Activities facilitating comprehension and retention of the content alongside with language skill-building.

3) Self-evaluation and feedback.

\section{Sample Task \#1 (BICS stage)}

Team 1. You will receive a list of questions for a survey. Move around the classroom and interview your fellow-students. Analyze the answers of the respondents and deliver a team report on the data collected.

Team 2. Answer the questions of the interviewers. Try to remember your first time at university in detail. Be specific about the things you did as well as your feelings. 
Sample Task \#2 (CALP stage)

You are a student counselor. Analyze the following problems first-year students face. Identify the stage of culture shock, specify the symptoms. Discuss possible solutions.

\begin{tabular}{|c|c|}
\hline Name & Problem \\
\hline Anna $S$. & $\begin{array}{l}\text { I feel very lonely here. I miss my home } \\
\text { and my old friends. I don't go out a lot } \\
\text { and I feel very different from others. }\end{array}$ \\
\hline Roma F. & $\begin{array}{l}\text { My roommate really annoys me! He } \\
\text { takes my things, even my laptop, doesn't } \\
\text { clean up the mess and is sooooo noisy! } 1 \\
\text { can't really change my room now, can I? }\end{array}$ \\
\hline Ivan $L$. & $\begin{array}{l}\text { University is ok. I already have some } \\
\text { friends here. We go out from time to } \\
\text { time. I have learnt to cook, so I don't go } \\
\text { hungry anymore. }\end{array}$ \\
\hline Vira $D$. & $\begin{array}{l}\text { It's so exciting here! There's so much to } \\
\text { do and see! I feel as if I've been born } \\
\text { again! The course is fantastic, the guys } \\
\text { are awesome! It's true that student years } \\
\text { are the best! }\end{array}$ \\
\hline
\end{tabular}

Sample Task \#3 (CALP stage):

You are a group of investors ready to allocate funds for three projects for freshmen. These aim to relieve the challenges of culture shock experienced by students in their first year at university. Each team is responsible for compiling a list of benefits of one project and a list of challenges of the other two. The task is to persuade the other teams that the project your team is in favour of is the most relevant in the present-day context.

Team 1: Counseling service for first-year students run by psychology majors.

Team 2: Tour club and field trips for freshmen organized by geography and PE majors.

Team 3: Debating society.

\section{Results and Discussion}

Classroom observation was completed according to a set of criteria featuring the triple learning goals and desired learning outcomes. The predominance of interactive methods in CLIL's classroom design determines a special status of the communicative culture of learners which led us to add a cultural dimension to the research procedure and enable to locate students' most typical communicative behaviors. With the research purpose only, the teachers were requested to fill in the observation forms after each CLIL session and also produce a set of field notes describing their impressions of the aspects not featured in the form. The latter were 
processed and added to research results. To ensure the validity of the research the observation was before the launch of the CLIL component and after it. The results of the observation are presented below.

Figure 1

Classroom observation report form (Before)

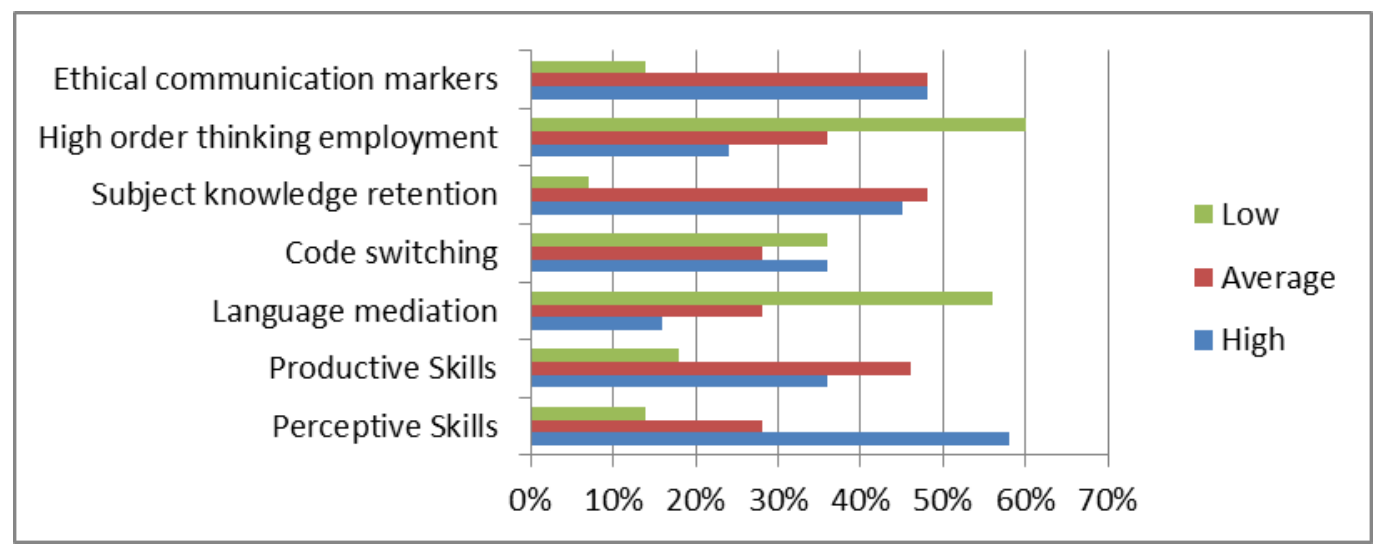

Figure 2

Classroom observation report form (After)

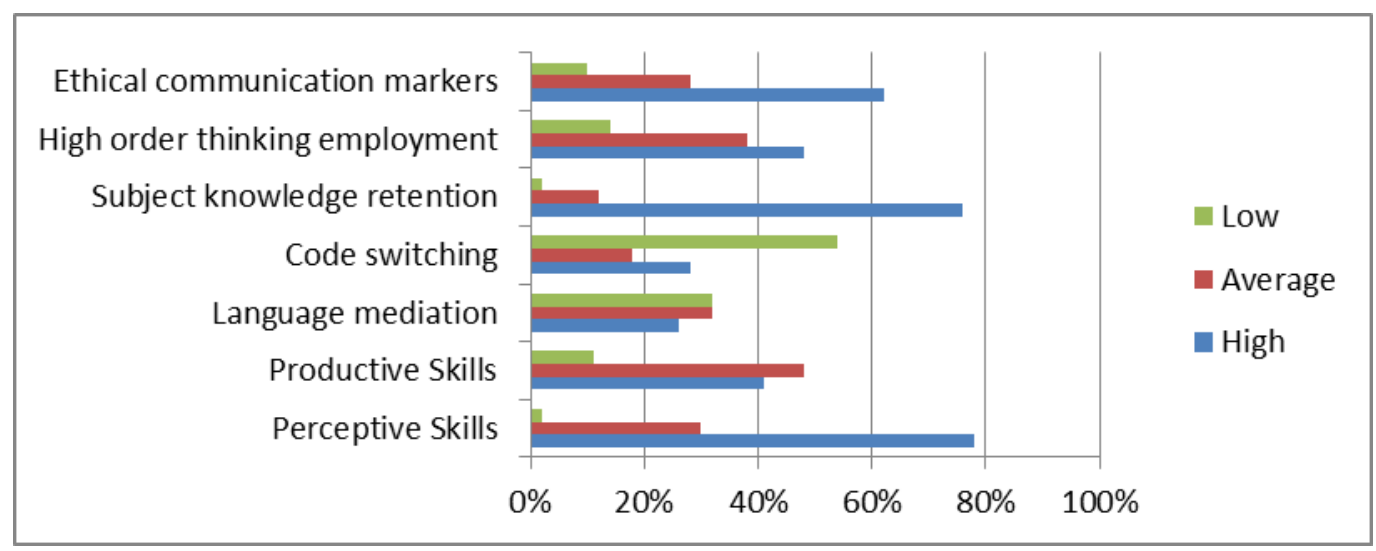

Table 2

Types of the students' communicative behaviors

\begin{tabular}{llll}
\hline & \multicolumn{3}{c}{ Communication Styles } \\
\cline { 2 - 4 } & $\begin{array}{l}\text { Inertial Style (14\% } \\
\text { before; 8\% after) }\end{array}$ & $\begin{array}{l}\text { Monopolization } \\
\text { Style (38\% before; } \\
24 \% \text { after) }\end{array}$ & $\begin{array}{l}\text { Ethical Style } \\
\text { (48\% before; } 68 \\
\text { after) }\end{array}$ \\
$\begin{array}{llll}\text { Perceptiveness to } \\
\text { other thinking } \\
\text { cultures }\end{array}$ & $\begin{array}{l}\text { Passive position in } \\
\text { interpersonal } \\
\text { communication. }\end{array}$ & $\begin{array}{l}\text { Rigid position in } \\
\text { perceiving the } \\
\text { partners } \\
\text { viewpoints. }\end{array}$ & $\begin{array}{l}\text { Readiness to } \\
\text { accept different } \\
\text { opinions. }\end{array}$ \\
& & & $\begin{array}{l}\text { Demonstrating } \\
\text { the value of }\end{array}$
\end{tabular}


communication.

$\begin{array}{llll}\text { Responsiveness } & \text { Lack of } & \text { Egocentric } & \text { Discourse } \\ \text { communicative } & \text { strategies in } & \text { markers } \\ \text { initiative; } & \text { cognitive and } & \text { demonstrating a } \\ \text { minimized } & \text { discussion } & \text { dialogical } \\ \text { feedback to the } & \text { strategies realized } & \text { disposition: } \\ \text { partner's remarks. } & \text { in regular } & \text { interpretation and } \\ \text { interruptions, } & \text { paraphrasal of the } \\ & \text { simulation of } & \text { partner's remarks; } \\ & \text { attention. } & \text { high feedbacking } \\ & & \text { on the partner's } \\ & & \text { remarks; } \\ & & \text { non-verbal } \\ & & \text { markers of } \\ & & \text { cooperative } \\ & & \text { behaviour. }\end{array}$

\begin{tabular}{|c|c|c|c|}
\hline $\begin{array}{l}\text { Cognitive } \\
\text { flexibility }\end{array}$ & $\begin{array}{l}\text { Passive position in } \\
\text { the content study; } \\
\text { Reproductive style } \\
\text { of reflection; } \\
\text { Low diversity of } \\
\text { perspective. }\end{array}$ & $\begin{array}{l}\text { Developing their } \\
\text { own perspectives; } \\
\text { No account is } \\
\text { made of the others' } \\
\text { remarks. } \\
\text { Demonstration of } \\
\text { prejudice and } \\
\text { antipathy. }\end{array}$ & $\begin{array}{l}\text { Demonstrating } \\
\text { tolerance towards } \\
\text { other students' } \\
\text { views and } \\
\text { perspectives; } \\
\text { Readiness to } \\
\text { adapt and } \\
\text { transform their } \\
\text { perspectives with } \\
\text { regard to their } \\
\text { partners"'. }\end{array}$ \\
\hline
\end{tabular}

The post-observation questionnaire survey was centered around three motivation biases: pragmatic, cognitive and that reflecting the need for personal growth. The post-observation interview enabled to collect the teachers' and students' feedback to the project and their reflections and perspectives on the benefits and restrictions of content-based approach in Ukrainian university settings.

The questionnaire contained nine items on a five-point Likert scale ranging from "strongly agree" to "strongly disagree" which tapped into students' selfidentified English learning needs which might be met through introduction of CLIL. The data derived were then finally submitted to descriptive analysis through SPSS and are summarized in the table below. 
Table 3

Questionnaire survey data analysis

\begin{tabular}{|c|c|c|}
\hline Motivation bias & $\%$ & Specific motivation markers \\
\hline \multirow[t]{3}{*}{ Pragmatic } & $12 \%$ & $\begin{array}{l}\text { Becoming a more knowledgeable and interesting } \\
\text { communicant able to hold intelligent } \\
\text { conversation and thus be more socially } \\
\text { attractive. }\end{array}$ \\
\hline & $16 \%$ & $\begin{array}{l}\text { Acquiring knowledge that may become a benefit } \\
\text { in the context of communication, networking } \\
\text { and career development in future. }\end{array}$ \\
\hline & $6 \%$ & $\begin{array}{l}\text { Obtaining material for instruction and sharing } \\
\text { that may favor the teacher's status and authority. }\end{array}$ \\
\hline Total: & $34 \%$ & \\
\hline \multirow[t]{3}{*}{ Cognitive } & $8 \%$ & $\begin{array}{l}\text { Learning vocabulary and content that never } \\
\text { appear through mainstream EGP and ESP } \\
\text { courses. }\end{array}$ \\
\hline & $18 \%$ & $\begin{array}{l}\text { Compensating for lack of factual knowledge } \\
\text { about the material world and social phenomena } \\
\text { experienced by pedagogy and philology majors. }\end{array}$ \\
\hline & $10 \%$ & $\begin{array}{l}\text { Receiving "insider" knowledge of the subject, } \\
\text { considering issues that refer to the inner } \\
\text { structure, action mechanisms or background } \\
\text { history of the subject. }\end{array}$ \\
\hline Total: & $36 \%$ & \\
\hline \multirow[t]{3}{*}{ Personal growth } & $8 \%$ & $\begin{array}{l}\text { Personal growth and self-actualization through } \\
\text { learning principally new things that do not occur } \\
\text { in the content of other degree or non-degree } \\
\text { courses. }\end{array}$ \\
\hline & $11 \%$ & $\begin{array}{l}\text { Acquiring confidence through the feeling of } \\
\text { growth appearing from expanding the world } \\
\text { outlook. }\end{array}$ \\
\hline & & $\begin{array}{l}\text { Enrichment of general knowledge as well as } \\
\text { language and communication skill building. }\end{array}$ \\
\hline
\end{tabular}

Total: $30 \%$ 
Both the students and the teachers involved in the CLIL pilot project brought forward two main conditions which should be observed in the pursuit of successful CLIL implementation: 1) Students' language proficiency must be sufficient in order to be able to grasp the linguistically loaded and academic subject matter. 2) Course material must have reference to knowledge that will be useful for future professional activity or at least contain some interesting, new and original information that may expand students' awareness of the surrounding world.

\section{Interview Excerpt 1:}

Teacher 1: Having to deal with language obstructions in cognition facilitates retention of knowledge and makes the process of cognition more exciting and memorable.

Teacher 2. CLIL gives a chance to actualize your intellectual potentials in high achieving students, who find it engaging to face an intellectual challenge and give vent to their ideas and perspectives. They have aptitude for high order thinking but do not get enough possibility to make use of it during a mainstream task-oriented EFL course.

\section{Interview Excerpt 2:}

Student 1. This is the kind of content through which identify our attitude to something and thus we cognate ourselves. It is a self-discovery in a way.

Student 2. CLIL being focused on content allows us not to focus on the accuracy of our speech. We just use it as a tool for cognition and communication.

\section{Conclusions}

In response to the first research question we set, it should be mentioned that the concept of CLIL in the university settings has to be distinguished from its counterparts - EMI and ESP. A systematic study of the relevant literature and the comparative analysis of the three approaches has led us to their clear differentiation according to which CLIL appears to be possible as a non-degree interdisciplinary course or syllabus component introduced to non-majors of the field.

The pilot project revealed unique potentials of CLIL in terms of acquisition of knowledge, expanding the awareness of students in non-degree areas, language skill building and high order thinking skills development. It may serve to the advantage of the high achieving contingent of the student population conferring them an opportunity to learn and develop to their full potential. Alongside rather than instead of the already existent EFL university courses CLIL may enhance diversification of university syllabi and lead student and teachers to an effective collaborative scheme of learning and development.

\section{References}

Григорьева К.С., Салехова Л.Л. Реализация принципов предметно-языкового интегрированного обучения с помощью технологий Web 2.0 в техническом вузе. Вестник РУДН. Серия ИНФОРМАТИЗАЦИЯ ОБРАЗОВАНИЯ. 2014. № 2. С. 11-18. Актуальні проблеми викладання іноземних мов для професійного спілкування : 
Матеріали Всеукр. наук.- практ. конф., 6-7 квіт. 2012 р. : У 3 т. Д. : Біла К.О., 2012.

C. 60-62. Retrieved from: http://www.confcontact.com/2012edu/2012edu_tom1.pdf.

Barrios, E., Lara, M. (2020). CLIL methodology, materials and resources, and assessment in a monolingual context: an analysis of stakeholders' perceptions in Andalusia. The Language Learning Journal, 48(1), 60-80.

Cummins, J. (1984). Bilingualism and Special Education. In Issues in Assessment and Pedagogy. Clevedon: Multilingual Matters.

Dafouz, E., Nunez, B., Sancho, C., \& Foran, D. (2007). Integrating CLIL at the Tertiary Level:

Teachers' and Students' Reactions in Diverse Contexts-converging Goals: CLIL in Europe, edited by D. Marsh and D. Wolff. (pp. 91-101). Frankfurt: Peter Lang.

Fortanet-Gómez, I. \& Bellés-Fortuño, B. (2008). The relevance of discourse markers in teacher training courses for Content and Language Integrated Learning in higher education. In O. Martí Arnáinz, \& M. P. Safont Jordá (Eds), Achieving multilingualism: Wills and ways. Proceedings of the First international conference on multilingualism (ICOM) (pp. 149159). Castelló de la Plana: Universitat Jaume I.

Graham, K. M, Choi, Y., Davoodi, A., Razmeh, S., \& Dixon L.Q. (2018). Language and Content Outcomes of CLIL and EMI: A Systematic Review. LACLIL, 11(1), 19-37.

Jiang, Li., Jun Zhang, L., \& May, S. (2019). Implementing English-Medium Instruction (EMI) in China: Teachers' Practices and Perceptions, and students' Learning Motivation and Needs. International Journal of Bilingual Education and Bilingualism. 22(2), 107-119.

Meyer, O. (2010). Introducing the CLIL-Pyramid: Key Strategies and Principles for CLIL Planning and Teaching. Basic issues in EFL Teaching and Learning, 295-313.

Lasagabaster, D., \& Sierra, J. (2010). Immersion and CLIL in English: More differences than similarities. ELT Journal, 64(4), 367-375.

Yang, W. (2016). ESP vs CLIL: A Coin of Two Sides or a Continuum of Two Extremes? ESP Today. Vol. 4(1). P.43-68.

\section{References (translated and transliterated)}

Grigorieva K.S., Salekhova L.L. (2014). Realizatsia printsipov predmetno-yazykovogo integrirovannogo obucheniya s pomoshchyu tekhnologiy Web $2.0 \mathrm{v}$ tekhnicheskom vuze. [Realisation of subject and language integrated learning principles using Web 2.0 technologies in higher technical school]. Vesnik RUDY. Seriya Informatizatsyia Obrazovaniya, 2, 11-18.

Znanetska, O. (2012) Osnovni dydaktychni ta metodychni pryntsypy vykladannia inozemnoyi movy [The main didactic and methodical principles of teaching foreign languages]. Aktualni problemy ykladannia inozemnykh mov dlia professiynoho spilkuvannia: materialy Vseukr. nauk.-prakt. konf., 6-7 kvit. 2012 r.: U 3 t. D.: Bila K.O. P. 60-62. Retrieved from http://www.confcontact.com/2012edu/2012edu_tom1.pdf

Barrios, E., Lara, M. (2020). CLIL methodology, materials and resources, and assessment in a monolingual context: an analysis of stakeholders' perceptions in Andalusia. The Language Learning Journal, 48(1), 60-80. https://doi.org/10.1080/09571736.2018.1544269.

Cummins, J. (1984). Bilingualism and Special Education. In Issues in Assessment and Pedagogy. Clevedon: Multilingual Matters.

Dafouz, E., Nunez, B., Sancho, C., \& Foran, D. (2007). Integrating CLIL at the Tertiary Level: Teachers' and Students' Reactions in Diverse Contexts-converging Goals: CLIL in Europe, edited by D. Marsh and D. Wolff. (pp. 91-101). Frankfurt: Peter Lang.

Fortanet-Gómez, I. \& Bellés-Fortuño, B. (2008). The relevance of discourse markers in teacher training courses for Content and Language Integrated Learning in higher education. In $\mathrm{O}$. Martí Arnáinz, \& M. P. Safont Jordá (Eds), Achieving multilingualism: Wills and ways. Proceedings of the First international conference on multilingualism (ICOM) (pp. 149159). Castelló de la Plana: Universitat Jaume I. 
Graham, K. M, Choi, Y., Davoodi, A., Razmeh, S., \& Dixon L.Q. (2018). Language and Content Outcomes of CLIL and EMI: A Systematic Review. LACLIL, 11(1), 19-37. https://doi.org/10.5294/laclil.v11i1.9268.

Jiang, Li., Jun Zhang, L., \& May, S. (2019). Implementing English-Medium Instruction (EMI) in China: Teachers' Practices and Perceptions, and students' Learning Motivation and Needs. International Journal of Bilingual Education and Bilingualism. 22(2), 107-119. https://doi.org/10.1080/13670050.2016.1231166.

Meyer, O. (2010). Introducing the CLIL-Pyramid: Key Strategies and Principles for CLIL Planning and Teaching. In M. Eisenmann, T. Summer, (Eds.). Basic issues in EFL Teaching and Learning, (pp. 295-313). Universitätsverlag Winter GmbH Heidelberg.

Lasagabaster, D., \& Sierra, J. (2010). Immersion and CLIL in English: More differences than similarities. ELT Journal, 64(4), 367-375. https://doi.org/10.1093/elt/ccp082.

Yang, W. (2016). ESP vs CLIL: A Coin of Two Sides or a Continuum of Two Extremes? ESP Today. 4(1), 43-68. Retrieved from https://www.researchgate.net/publication/ 299615961_ESP_vs_CLIL_A_coin_of_two_sides_or_a_continuum_of_two_extremes.

\section{Appendix}

Conceptual Features of CLIL, ESP and EMI in Comparison and Contrast

\begin{tabular}{|c|c|c|c|c|}
\hline & & ESP & EMI & CLIL \\
\hline 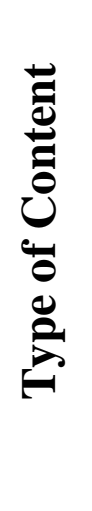 & & $\begin{array}{l}\text { Subject matter } \\
\text { reflecting professional } \\
\text { trivia, elements of } \\
\text { expert knowledge and } \\
\text { situations of } \\
\text { professional } \\
\text { communication partially } \\
\text { duplicated in L1 degree } \\
\text { courses. }\end{array}$ & $\begin{array}{l}\text { Degree-based } \\
\text { content, domain } \\
\text { knowledge replicated } \\
\text { from L1 curricular. }\end{array}$ & $\begin{array}{l}\text { Interdisciplinary } \\
\text { cross-curricular } \\
\text { content designed for } \\
\text { non-majors of the } \\
\text { field. }\end{array}$ \\
\hline 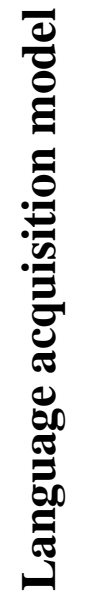 & 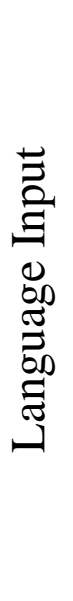 & $\begin{array}{l}\text { Lexis being of } \\
\text { paramount importance, } \\
\text { inc. terminology of the } \\
\text { specific field and } \\
\text { general academic } \\
\text { vocabulary, relevant } \\
\text { grammar patterns } \\
\text { constitute an important } \\
\text { aspect of language input } \\
\text { as well. }\end{array}$ & $\begin{array}{l}\text { Language learning } \\
\text { does not occur as } \\
\text { such since the former } \\
\text { serves as a medium } \\
\text { of communicating } \\
\text { expertise and does } \\
\text { not belong to the } \\
\text { objectives of the } \\
\text { course. }\end{array}$ & $\begin{array}{l}\text { Double focus on } \\
\text { language and } \\
\text { content. Vocabulary } \\
\text { and relevant } \\
\text { grammar are } \\
\text { introduced } \\
\text { separately to relieve } \\
\text { possible cognitive } \\
\text { obstructions. }\end{array}$ \\
\hline
\end{tabular}




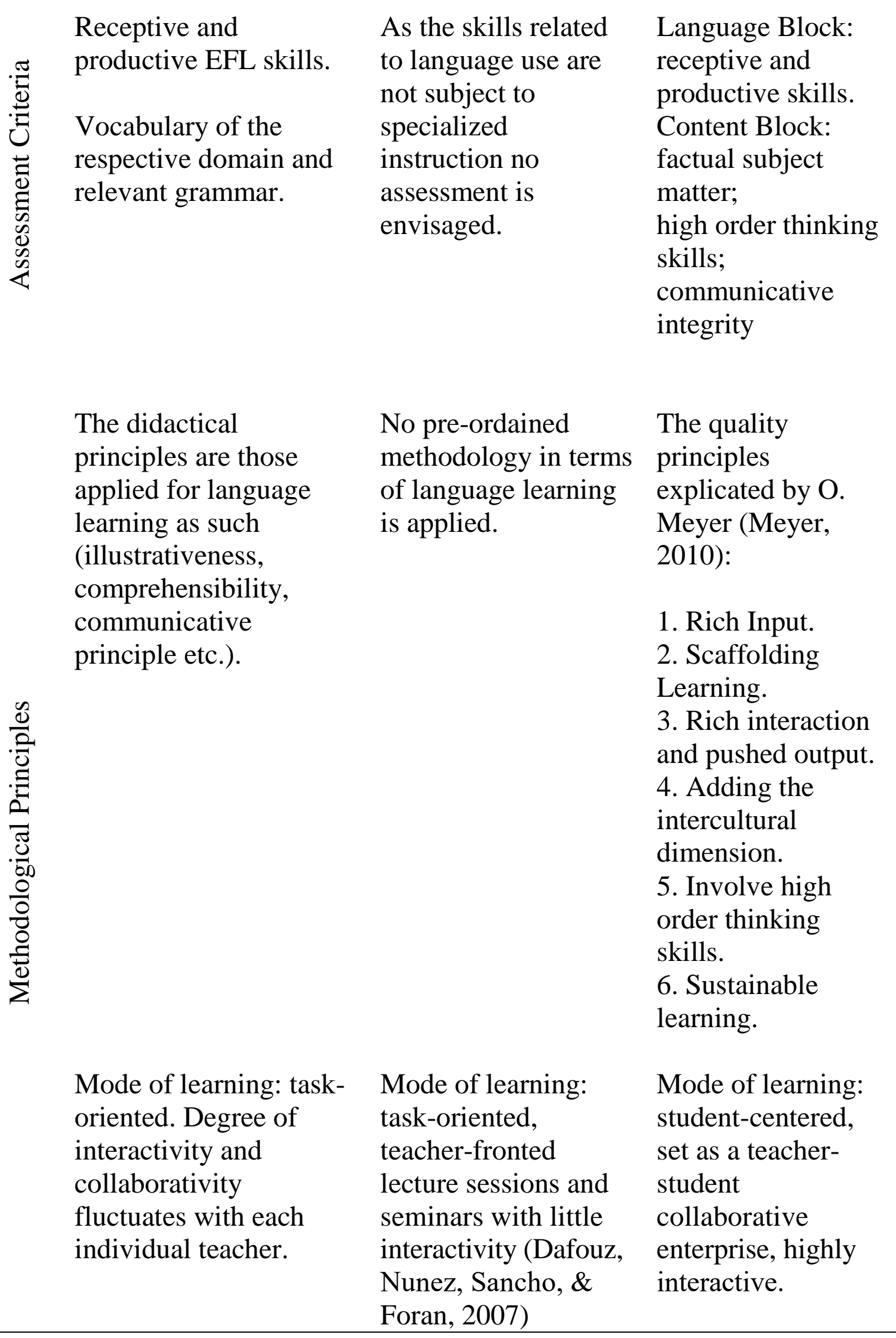




\begin{tabular}{|c|c|c|}
\hline $\begin{array}{l}\text { Language learning is } \\
\text { performed according to } \\
\text { an algorithmic } \\
\text { methodological scheme. } \\
\text { Receptive and } \\
\text { productive skills } \\
\text { undergo special training } \\
\text { through an elaborate set } \\
\text { of exercises. }\end{array}$ & $\begin{array}{l}\text { The methodology } \\
\text { pertains to the } \\
\text { immersion pattern } \\
\text { which is introduced } \\
\text { simultaneously with } \\
\text { the syllabus-based } \\
\text { theory of the major } \\
\text { course. }\end{array}$ & $\begin{array}{l}\text { BICS } \rightarrow \text { CALP, } \\
\text { group and pair } \\
\text { work, active } \\
\text { methods of } \\
\text { learning, problem- } \\
\text { based learning, } \\
\text { project, } \\
\text { presentation, team } \\
\text { building games, use } \\
\text { of graphic } \\
\text { organizers, mind } \\
\text { maps and } \\
\text { infographics. }\end{array}$ \\
\hline
\end{tabular}

